\title{
Wax-ester reserves facilitate dispersal of hydrothermal vent shrimps
}

\author{
David Pond $^{1,2, *}$, David Dixon ${ }^{1}$, John Sargent ${ }^{2}$ \\ 'Plymouth Marine Laboratory, Prospect Place, Plymouth PL1 3DH, United Kingdom \\ ${ }^{2}$ NERC Unit of Aquatic Biochemistry, Department of Biological and Molecular Sciences, University of Stirling, Stirling FK9 4 LA, United Kingdom
}

\begin{abstract}
Late zoeal and early postlarval stages of vent shrimp (Rimicaris exoculata, Chorocaris chacei and Alvinocaris markensis), sampled from the water column above the Broken Spur vent site (mid-Atlantic Ridge), contained large amounts of bright orange coloured lipid in their thoracic and abdominal regions. The lipid comprised 75 to $82 \%$ wax ester, containing predominantly $16: 0$ and 18:1 fatty alcohols. In contrast, wax esters were found to be absent in samples of adult vent shrimp ( $R$. exoculata and $A$. markensis). Substantial wax-ester reserves are a recognised adaptation to a prolonged bathypelagic, planktotrophic existence in deep-sea organisms where food is scarce and they have to survive extended periods without teeding. This characteristic is clearly of benefit to larval vent shrimp, which appear to be the main dispersal phase in the life history of these organisms whose adult stages inhabit a strikingly ephemeral environment which is discontinuous in both space and time.
\end{abstract}

KEY WORDS: Hydrothermal vent shrimps - Larval dispersal Wax esters

Although various aspects of the ecology and the trophic dynamics of vent shrimp have been addressed (Van Dover 1995), fundamental questions, such as the mechanism of their population dispersal, remain unresolved. To address this issue we analysed the lipids (which can give valuable insights into the life history strategies of marine organisms; Sargent \& Henderson 1986) of late zoeal stage and early postlarval stage bresiliid shrimp (16 to $22 \mathrm{~mm}$ ) sampled from between 200 and $1000 \mathrm{~m}$ above the seabed in a hydrothermally active segment of the mid-Atlantic Ridge. Surfaceoperated nets (RMT1+8) were trawled within the Broken Spur segment (latitude $29^{\circ} 10^{\prime} \mathrm{N}$ ) during RRS 'Charles Darwin' cruise 95 (chief scientist: B. J. Murton) in August 1995 (Herring 1996). The shrimp larvae

•E-mail:d.pond@pml.ac.uk
(Rimicaris exoculata, Chorocaris chacei and Alvinocaris markensis; Dixon \& Dixon 1996) all contained substantial orange-pigmented lipid reserves in their thoracic region and in a vacuole located beneath the anterior part of the abdomen. High performance thin layer chromatography indicated that these lipid vacoules comprised 75 to $82 \%$ wax esters. Wax esters were found to be absent in specimens of adult $R$. exoculata and $A$. markensis (no samples of adult $C$. chace were available for analysis).

Genetic analysis of adult Rimicaris exoculata from the TAG and Broken Spur vent sites has indicated low genetic diversity (Creasey et al. 1996), suggesting an effective mechanism of dispersal, although at which stage, larval or adult, dispersal occurs in these organisms was unclear. As distances between vent fields can be considerable (hundreds of kilometres), this implies a considerable period of time spent away from the vent food source. A characteristic of hydrothermal vents is the high temporal and spatial instability linked to variations in magmatic heat convection and tectonic activity along the ridge axis (Tunnicliffe 1991). Due to their nutritional dependence on vent-derived materials, vent organisms live under the constant threat of extinction, at least on a local scale, unless they are able to colonise new vents as these become active and before old vents die. It has been suggested that the cold ambient bottom waters associated with the deep ocean ( 2 to $3^{\circ} \mathrm{C}$ ) could lower metabolic and developmental rates, enabling the pelagic larvae of vent organisms to remain in the plankton for prolonged periods (Lutz et al. 1984). However, the presence of wax esters in marine zooplankton is characteristic of organisms which inhabit environments subject to marked fluctuations in food availability and enables organisms to survive considerable periods without feeding (Lee \& 
Table 1. Rimicaris exoculata, Alvinocanis markinses and Chorocaris chacei. Fatty acid and fatty alcohol composition ( $\%$ weight) of total lipid from late zoeal stage and early post-larval stage bresiliid shrimp collected from the water column above the Broken Spur hydrothermal vent, mid-Atlantic Ridge. Only mean (SE) values of major components are shown for clarity, $\mathrm{n}=8$

\begin{tabular}{|rrc|} 
& Fatty acid & Fatty alcohol \\
\hline $16: 0$ & $7.3(0.8)$ & $47.7(1.6)$ \\
$16: 1(n-7)$ & $21.0(2.0)$ & $13.5(1.5)$ \\
$18: 0$ & $1.7(0.2)$ & $18.8(0.5)$ \\
$18: 1(n-9)$ & $24.1(1.5)$ & $18.1(0.7)$ \\
$18: 1(n-7)$ & $8.8(0.7)$ & \\
$18: 2(n-6)$ & $2.7(0.04)$ & \\
$20: 4(n-6)$ & $3.0(0.4)$ & \\
$20: 5(n-3)$ & $6.7(0.8)$ & \\
$22: 6(n-3)$ & $12.9(2.1)$ & \\
\hline
\end{tabular}

Hirota 1973). Indeed, wax esters are very abundant in many bathypelagic fish and crustacea which are known to feed intermittently (Sargent 1976). The wax esters of the vent shrimp late zoeal stages and postlarvae are typically bathypelagic, containing predominantly 16:0 and 18:1 fatty alcohols. It is also notable that the fatty acids are rich in 20:5(n-3) and 22:6(n-3), establishing (at least in part) an origin in the euphotic zone (Table 1).

The substantial wax-ester reserves we observed in the larvae indicate that these early life history stages are adapted to a bathypelagic lifestyle, enabling them to maintain a prolonged planktotrophic existence and thus facilitating widespread dispersal in their search for new vents.

This note was submitted to the editor
Acknowledgements. We thank Dr M. Segonzac, IFREMER, Brest, for providing specimens of adult shrimp and Dr $M$. Saint-Laurent, Museum of Paris, for identifying the larval stages. This work was funded in part by 2 NERC BRIDGE grants (GST/02/1125 and GST/02/1143) and by the EUMAST 3 programme (AMORES: PL950040). D.P. was supported by an NERC-PRIME grant (GST/02/1075). This is PRIME contribution number 16 .

\section{LITERATURE CITED}

Creasey S, Rogers AD, Tyler PA (1996) Genetic comparison of two populations of deep-sea vent shrimp Rimicaris exoculata (Decapoda: Bresiliidae) from the Mid-Atlantic Ridge. Mar Biol 125:473-482

Dixon DR, Dixon LRJ (1996) Results of DNA analyses conducted on vent-shrimp postlarvae collected above the Broken Spur vent field during CD95 cruise, August 1995. BRIDGE Newsletter 11:9-15

Herring PJ (1996) Travelling shrimp. BRIDGE Newsletter 11: $6-8$

Lee RF. Hirota J (1973) Wax esters in tropical zooplankton and nekton and the geographical distribution of wax esters in marine copepods. Limnol Oceanogr 18:227-239

Lutz RA, Jablonski D, Turner RD (1984) Larval development and dispersal at deep sea hydrothermal vents. Science 226:1451-1453

Sargent JR (1976) The structure, metabolism and function of lipids in marine organisms. In: Malins DC, Sargent JR (eds) Biochemical and biophysical perspectives in marine biology. Academic Press, London, p 149-212

Sargent JR, Henderson RJ (1986) Lipids. In: Corner EDS, O'Hara SCM (eds) The biological chemistry of marine copepods. Clarendon Press, Oxford, p 58-108

Tunnicliffe $V$ (1991) The biology of hydrothermal vents: ecology and evolution. Oceanog Mar Biol Annu Rev 29: 319-407

Van Dover CL (1995) Ecology of Mid-Atlantic Ridge hydrothermal vents. In: Parson LM, Walker CL, Dixon DR (eds) Hydrothermal vents and processes. The Geological Society, London, p 257-294

Manuscript first received: November 8,1996 Revised version accepted: December 23, 1996 